\title{
Selecting Educational Resources ${ }^{1}$
}

\author{
Tyler D’Angelo, Deb Barry, J. C. Bunch, and Andrew Thoron²
}

\section{Introduction}

Educators should plan learning experiences that not only align with the instructional goals, but also support the learners in mastering the learning objectives that have been outlined in the lesson plan. Many instructors struggle to find appropriate educational resources because they often lack the knowledge of available materials. Educators often feel overwhelmed while sifting through a plethora of resources because it can become a time-consuming process. However, collaborative teaching and learning efforts have created a number of educational resources that can be stored, shared, adapted, and used within the agricultural education profession. Selecting the appropriate learning resource is vital to instruction because it will help guide learners to meet the instructional goals.

\section{Considering Learning Resources}

When first selecting a learning resource, it is important to consider what the learning objectives are for that lesson. Learning objectives should help guide the lesson, rather than selecting a resource and deciding a learning objective afterward. While choosing resources, educators will discover that the resource they have selected may not appropriately align with the content as intended. However, many instructors can be persuaded to use something new when it may not specifically apply to a particular lesson. Educators may also discover that the resource they have selected may not be suitable for the age, emotional development, skill level, and preferred learning styles of the students. It is important to review the resource before utilizing it in a classroom. The resource selected should support the lesson and be consistent with the learning outcomes. This may require the instructor to modify the resource for specific classroom use.

Using biased or slanted learning resources may also be used to meet specific instructional outcomes. This is usually done so that students utilize critical-thinking skills in order to recognize propaganda. Using learning resources that center around controversial issues should be selected with a focus on various views in other resources. Such resources might be chosen to show how stances on issues may vary based on belief. Using varying resources on controversial issues helps learners to gather a wide stance on issues relating to policy, social interaction, and moral viewpoints.

\section{Learning Resource Methodologies}

When utilizing instructional resources in a classroom, it is suggested that the resources fit to the preferred learning styles of the learners (Department of Education, 2008). Typically, the learning resources should be mostly activitybased rather than lecture-based. However, an instructor may find a resource that utilizes both effectively. Great learning resources also utilize co-operative learning, as well as provide the opportunity for individual growth through feedback. Some of the best resources available in agricultural education utilize hands-on learning activities for an applied method to learning. Great learning resources should also engage students in classroom inquiry

1. This document is AEC640, one of a series of the Agricultural Education and Communication Department, UF/IFAS Extension. Original publication date June 2018. Visit the EDIS website at http://edis.ifas.ufl.edu.

2. Tyler D'Angelo, graduate student; Debra Barry, lecturer; J. C. Bunch, assistant professor; and Andrew Thoron, associate professor; Department of Agricultural Education and Communication, UF/IFAS Extension, Gainesville, FL 32611. 
by encouraging students to question, think, reflect, and create connections from scientific knowledge in ways that develop critical-thinking and decision-making skills. Finally, a learning resource should offer flexibility to meet learners' needs. The individual abilities, learning styles, multiple intelligences, and interests of students should be considered.

\section{Information-Based Resources}

Information-based resources are resources that are simply content-related resources. Some examples may include online library resources, databases, and professionals in a given field. When considering an information-based resource, it is important to consider what information is being presented and how that information will translate to the learner. There are not always lesson plans created for information-based resources, so it is the instructor's responsibility to take the content and create effective learning activities.

Examples: UF/IFAS Website, Florida Farm Bureau

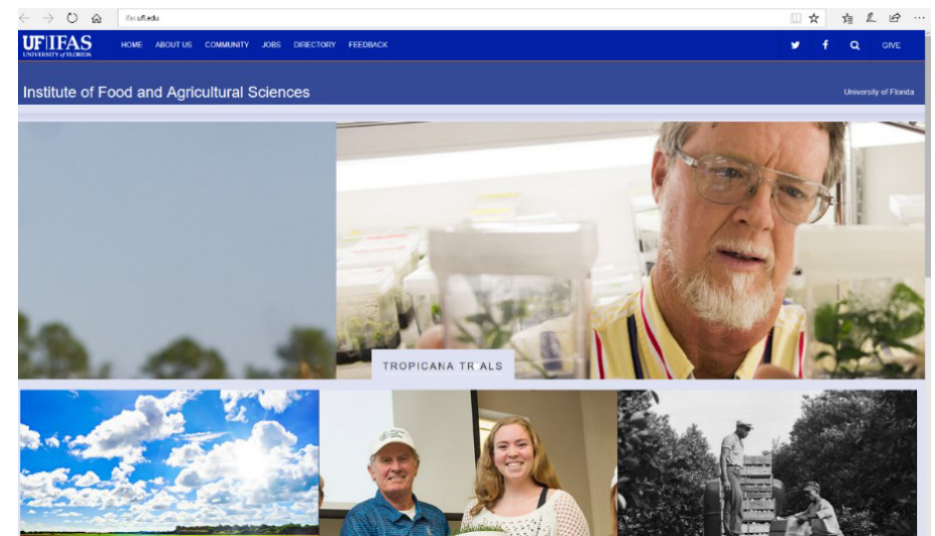

Figure 1. The UF/IFAS website is a great resource for Florida educators because it offers information about current Extension and research projects. Many of the articles that are within the UF/IFAS website can easily be accessed and used as supplemental readings, or used to create a lesson around the content on the website (retrieved from http://ifas.ufl.edu/).

\section{File Sharing Resources}

File sharing resources are a useful resource because educators who use these resources are often able to modify the resources for their specific learners. File sharing resources usually include a lesson plan and appendices for teacher use. Educators use these resources because they are accessible, easy to modify, and are typically proven to be effective instructional materials because they have already been used in a classroom.
Examples: NAAE Communities of Practice, Ag Education Discussion Lab, Georgia Agricultural Education, U of I AGED Curriculum Materials

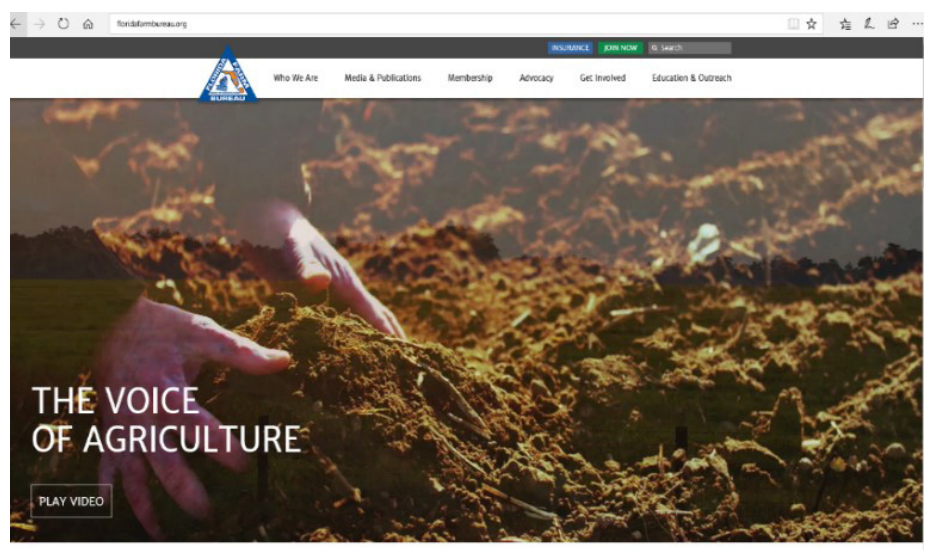

Figure 2. The Florida Farm Bureau website is a great resource that has information regarding current legislative issues relating to agriculture and environmental sciences. This resource should be consulted when discussing debatable issues relating to agriculture and natural resources. This website also has links to opportunities in and outside of the classroom, such as $\mathrm{Ag}$ in the Classroom and the annual Youth Speech Contest (retrieved from http://www.floridafarmbureau.org/ education-outreach/).

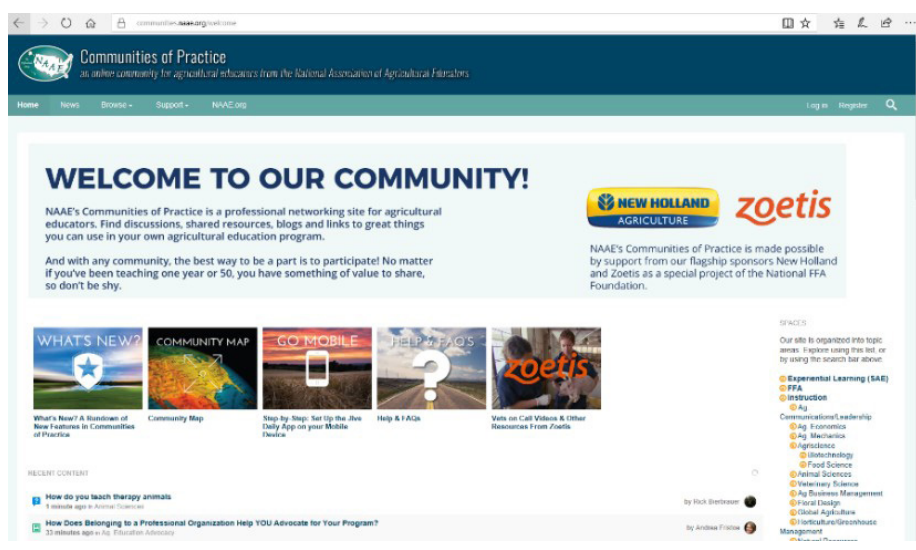

Figure 3. The Communities of Practice is housed within the National Association of Agricultural Educators. Current agricultural educators can upload lesson plans or additional classroom resources to shar eafter making a profile on the website. In the top right corner, you can search for a lesson topic that you would like to find (retrieved from https://communities.naae.org/welcome).

\section{Lesson Plans Provided by Organizations}

Lesson plans provided by organizations are created so that they are not only available to educators, but that they also advance their organization. While these types of lesson plans are typically free, they may have supplemental materials that an educator can purchase through their website if they do not already have it in their classroom. Lesson plans from organizations are often created through grant funding or through educational outreach projects that the 
organization serves. Organizations create lesson materials to help advance awareness in content areas in which the organizations serve.

Examples: National FFA, AET, National Agriculture in the Classroom, Florida Agriculture in the Classroom, American Farm Bureau, America’s Heartland
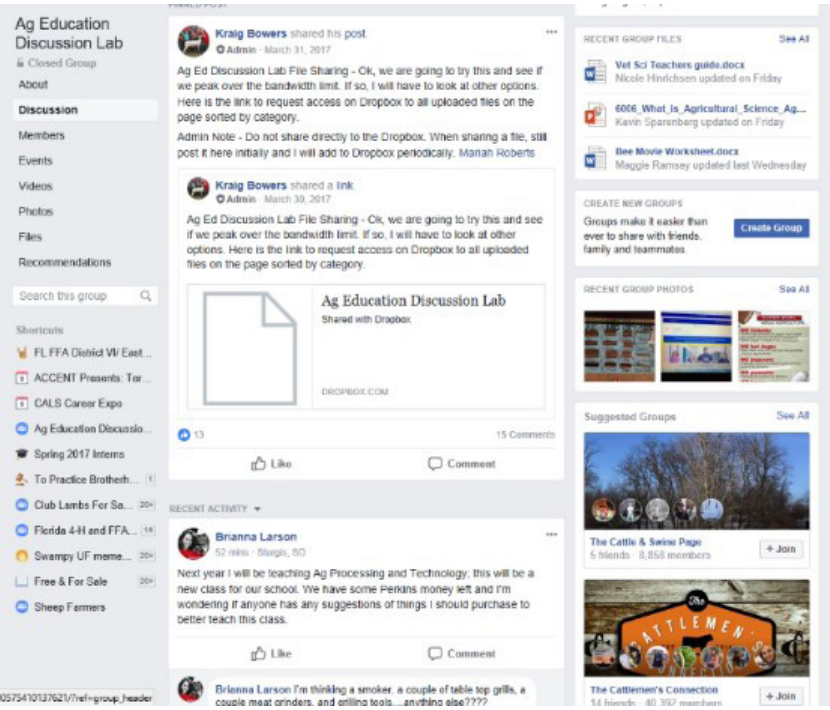

Figure 4. The Ag Education Discussion Lab is a closed group on Facebook where educators can upload lesson plans and resources. In the left-hand corner, you can search for a lesson topic. The Ag Education Discussion Lab also has a Dropbox account that educators can join, listed at the top of the page. The lesson topics in the Dropbox are sorted by category (retrieved from https://www.facebook.com/gro ups/400575410137621/?ref=bookmarks).

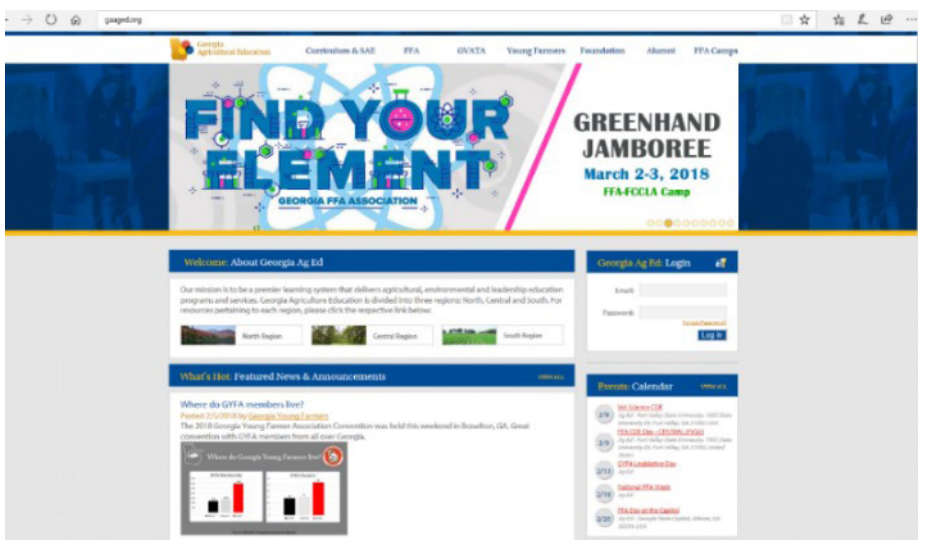

Figure 5. The Georgia Agricultural Education website offers over 4,000 lesson plans for middle and high school students in a variety of content areas within agriculture. On the home page, you will click, "Curriculum \& SAE," and then click on "Curriculum". The website also has various PowerPoints included to go with the lesson plans (retrieved from http://www.gaaged.org/aged/).

\section{Fee-Based Instructional Materials}

Fee-based instructional materials are created by organizations who seek to gain profit on curriculum materials. These curriculum materials are typically of high quality.
Fee-based resources provide lessons that can be used throughout the school year, and often have other features that an instructor may access and utilize through their website. Unfortunately, the instructional materials from fee-based resources have significant costs for the educator. An educator could gain access to these curriculum materials through funding from external sources, such as school administration or scholarships, offered through the organization.

\section{Examples: CASE, MyCAERT}

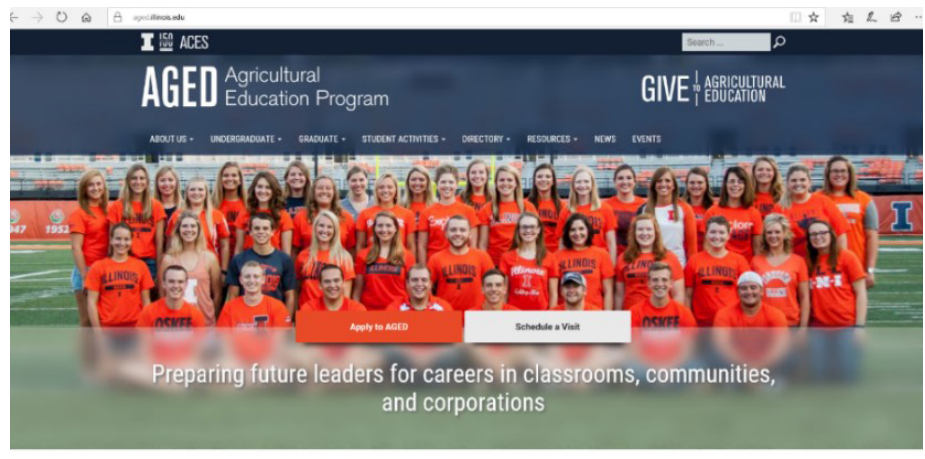

Lead, Teach, Inspire

Figure 6. The University of Illinois Agricultural Education website contains materials for agricultural educations in a variety of content areas. Once on the home page, click "Resources". In the drop-down menu, you will find a link to "Curriculum Materials" (retrieved from http://www.agriculturaleducation.org/Educator-Resources).

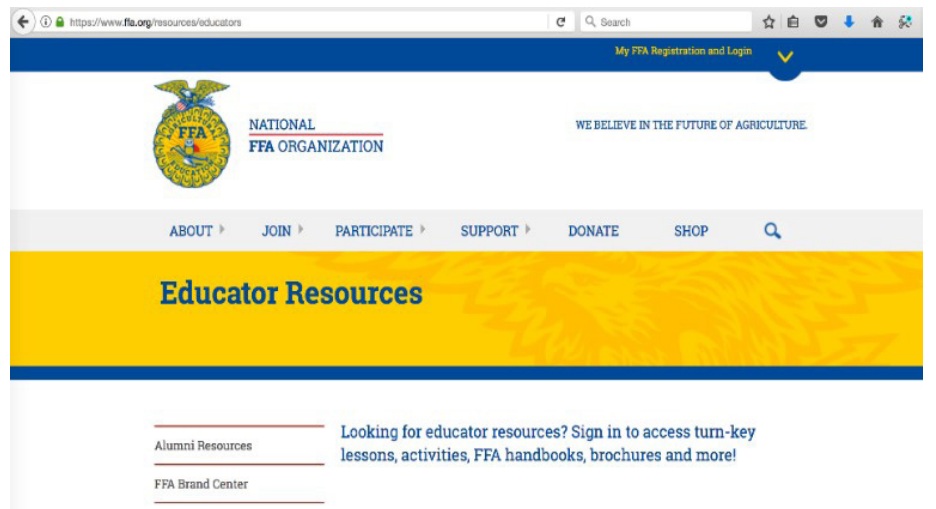

Figure 7. Once on the National FFA home page, you should sign in with your account information for MyFFA. If you do not have a MyFFA account, you can easily make an account on the website under, "My FFA Login". After logging in, search the website by typing "Educator Resources" in the top right corner. National FFA provides a plethora of resources for educators relating to FFA, horticulture, animal sciences, and more (retrieved from https://www.ffa.org/resources/educators).

\section{Web-Based Inquiry Resources}

Web-based inquiry resources are often modules, simulations, and demonstrations that are offered online to students. These resources can best be utilized in courses where each student has access to a computer with internet access. While there are other ways these resources can be 
used without individual student access to a computer, these resources offer students access to hands-on activities that might not be available otherwise. These resources integrate technology with student learning modalities. Web-based inquiry resources may or may not be accompanied by a lesson plan.

Examples: WISE, Sketchfab, Labster, National Science Digital Library

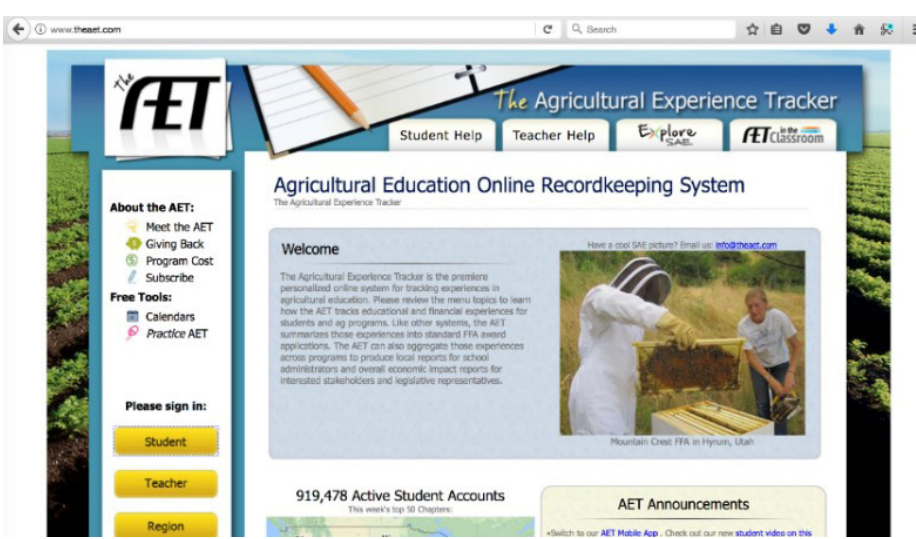

Figure 8. Once signed in to the AET website, you can access a number of curriculum resources and lesson plans under the "Teacher Help" tab. This website offers a multitude of resources, particularly for tracking SAE projects and FFA program resources. The teacher help page also has instructional videos to help educators navigate through the website (retrieved from http://learn.theaet.com/default. aspx?ID=7450).

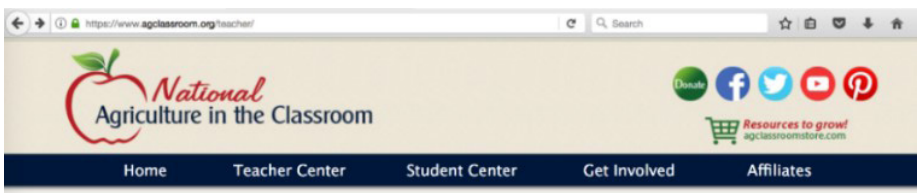

Teacher Center

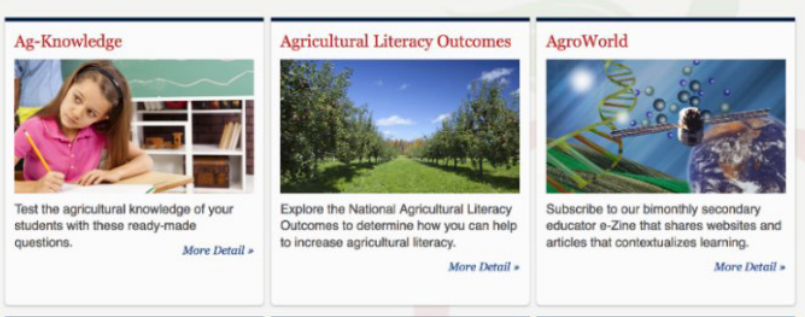

Figure 9. The National Agriculture in The Classroom website offers lesson plans, scholarships, and curriculum matrixes that can be adapted for classroom-specific use from the elementary level to secondary level. The resource offers classroom lab aid kits that can be purchased with lessons they have created. The National Agriculture in the Classroom resource is based at the state level and was created with the help of the American Farm Bureau (retrieved from https:// agclassroom.org/teacher/index.cfm).

\section{Conclusion}

Learning resources help instructors create a series of lesson plans that help learners master the learning objectives. It is important to utilize a variety of learning modalities when selecting learning resources so that you tailor the learning needs to a variety of learners. When selecting a resource, it is important to consider your specific learning objective. Certain resources are more suitable, depending on the lesson. The resources shared within this publication are not endorsed by the University of Florida and the Institute of Food \& Agricultural Sciences (UF/IFAS) because they share conflicting views.

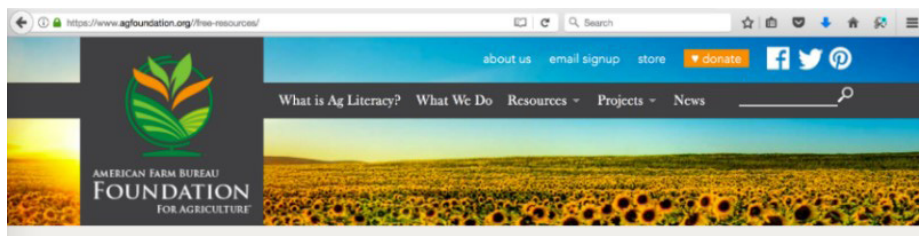

\section{Free Resources \& Lesson Plans}

Downloadable activities and lesson plans about agriculture and links to more agricultural education materials. For even more suggestions check out our Food \& Ag Resource Guide.
Figure 10. The American Farm Bureau Foundation for Agriculture offers a number of resources that can be utilized in the classroom on a variety of topics. This website also sells lab kits that can be used in a classroom. This resource lists lesson plans from the kindergarten level to the secondary level. In one of the resources, there are a list of games that can be incorporated within the classroom (retrieved from http://www.agfoundation.org/free-resources/).

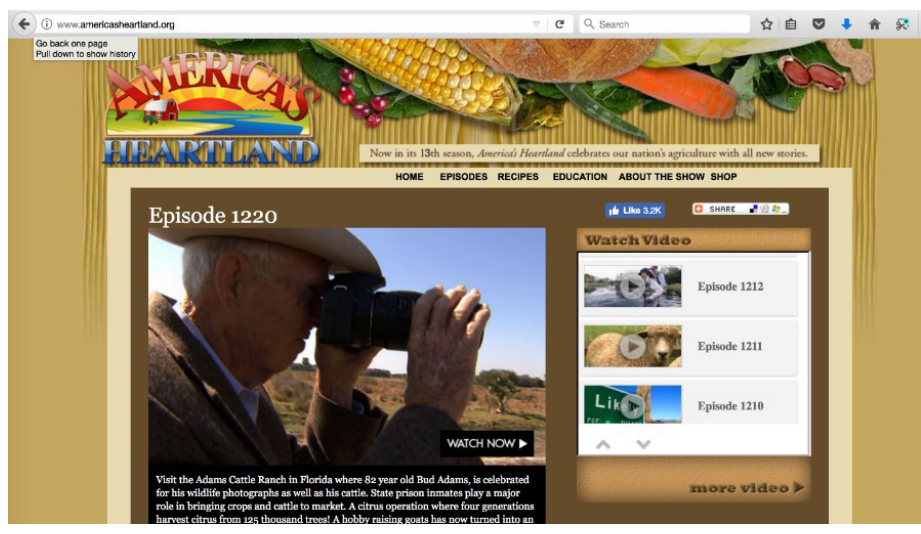

Figure 11. America's Heartland offers a range of lesson plans from careers in agriculture to food science technology. This resource also has a number of videos that can be shared in the classroom. America's heartland has 12 seasons of various videos that highlight various agricultural producers from around the nation (retrieved from http:// www.americasheartland.org/education/teachers/index.html).

When selecting a resource, it is important to use a resource that is beneficial to your classroom use and need. Information-based resources are utilized to help students gather information on issues affecting agricultural and life sciences. File sharing and organizational resources can be used and modified for an instructor's specific use in a variety of content areas. Web-based inquiry resources offer a wide variety of activities that integrate technology for effective instruction. Learning resources help students master 
the course material. Learning resources also help instructors create effective pedagogy for learners. Using effective resources helps learners master content while efficiently helping instructors create meaningful instruction.

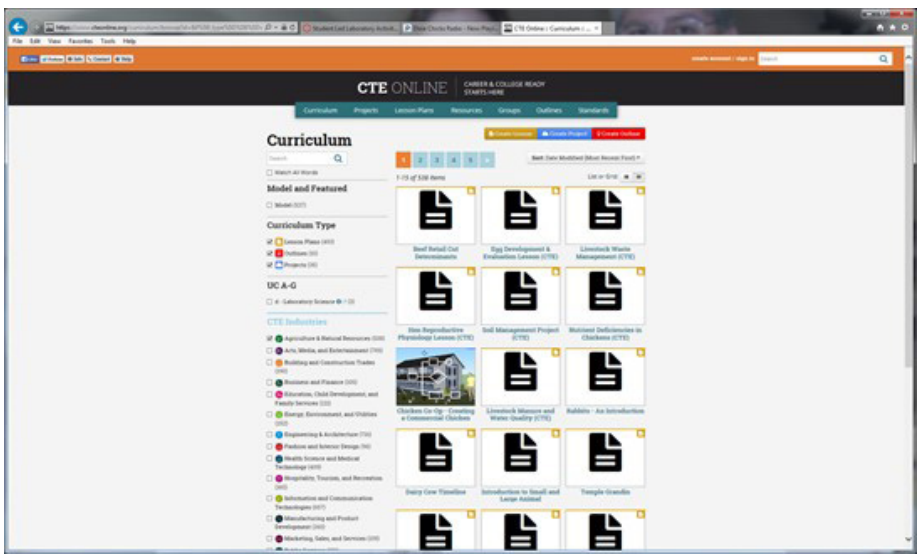

Figure 12. CTE Online is a comprehensive career and college readiness resource. The search function allows users to select their content area, including agriculture \& natural resources. Users can search for lesson plans, outlines, and projects. The site is maintained by the Butte County Office of Education's Center for the Advancement of Digital Resources in Education (retrieved from https://www.cteonline.org/).

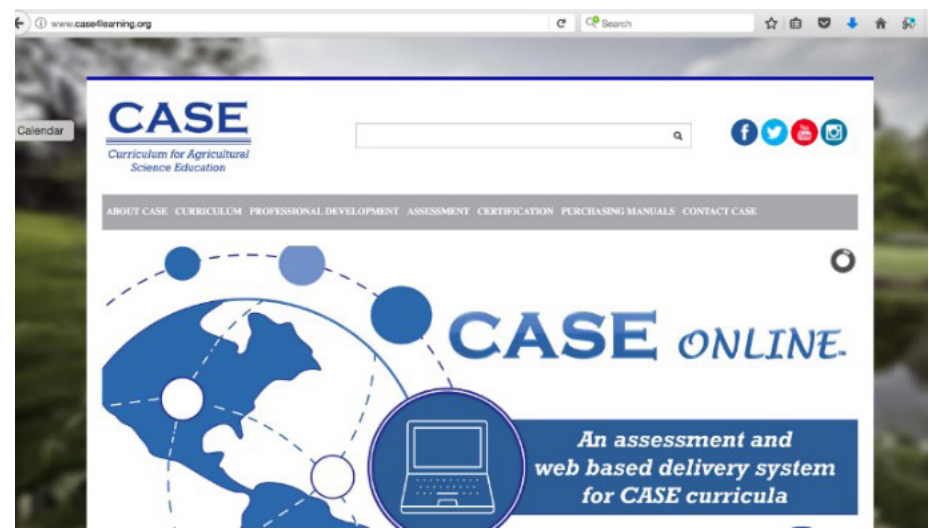

Figure 13. CASE is a year-long set of inquiry-based curriculum that engages students through various content pathways. In order to access the curriculum, the educator must be certified through a CASE Institute in one of the content-focused areas. While the certification and the curriculum can be costly, CASE offers a variety of scholarships to help pay for the curriculum. There are also opportunities to have your local school board help pay for the certification (retrieved from http://www.case4learning.org/).

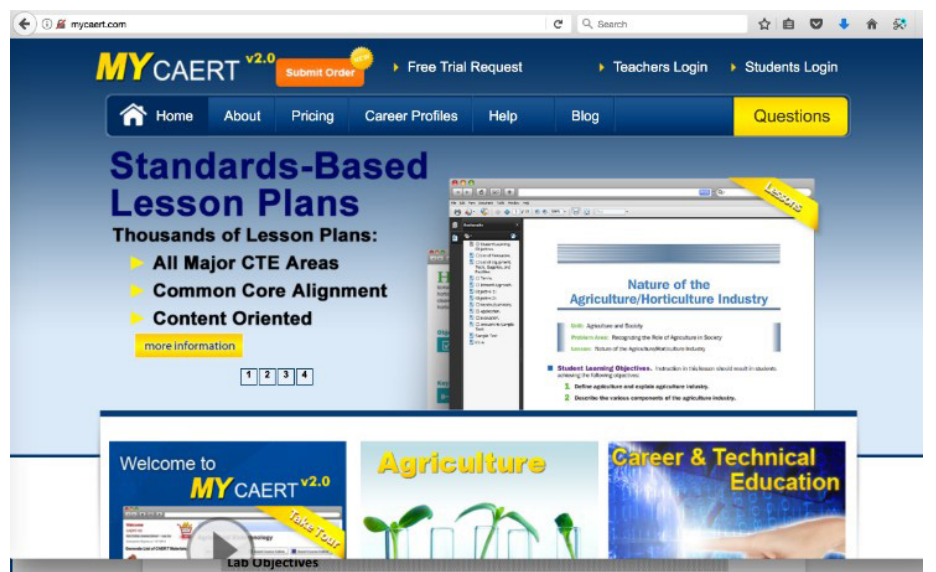

Figure 14. MyCAERT offers thousands of lesson plans and resource materials that can be utilized in a classroom. In order to access the curriculum, the teacher must be a paid member of the curriculum. This curriculum is unique because it allows students to make profiles on the website and have a student account where teachers can assign coursework. A free trail can be requested for use before purchase (retrieved from http://mycaert.com/).
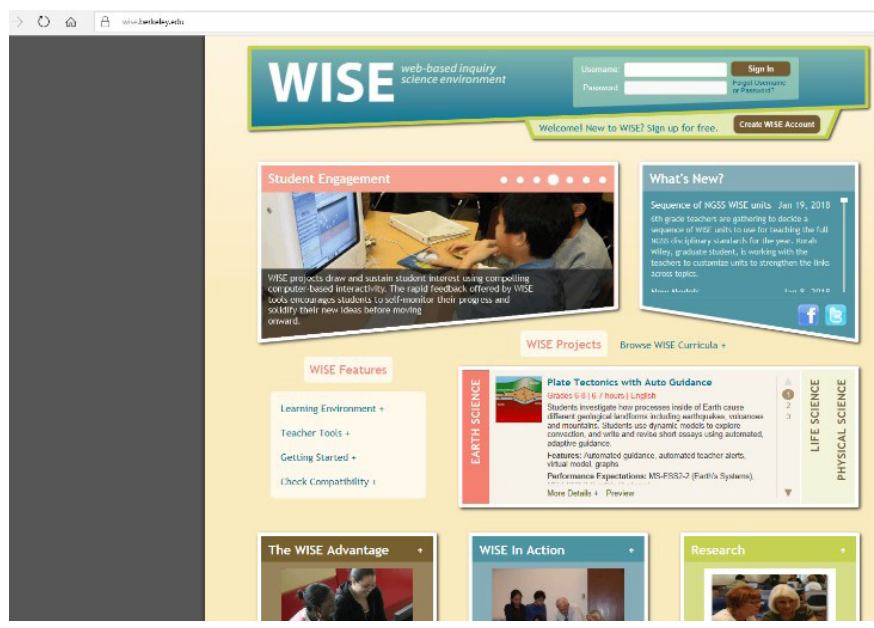

Figure 15. WISE, which stands for Web-based Inquiry Science Environment, is a website that offers a variety of interactive models, simulations, teacher tools, and open resources. After making a free account on the website, teachers can access the entire curriculum given. While this resource is not specifically agricultural educationdriven, it does offer a variety of resources in general biology, physical science, environmental science, and horticulture (retrieved from https://wise.berkeley.edu/). 


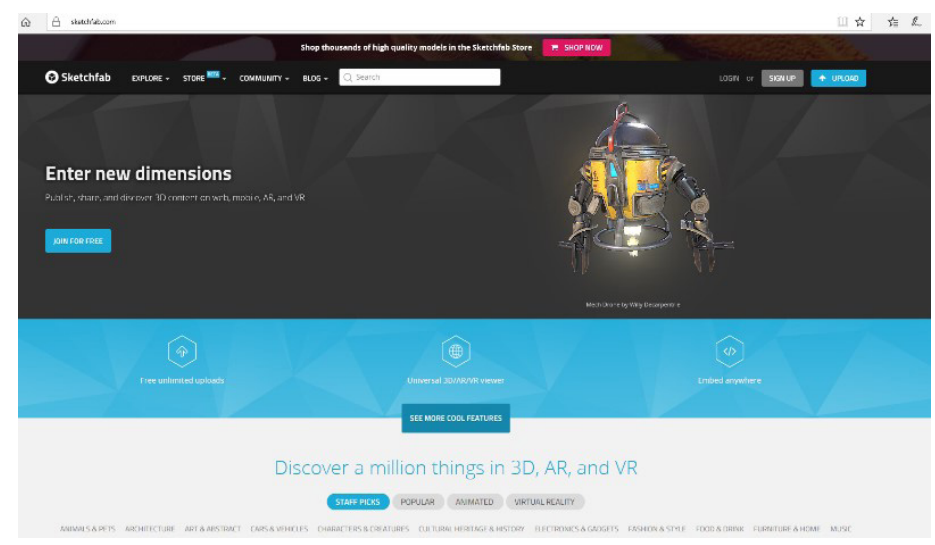

Figure 16. Sketchfab is a website that allows students to build and view models of various ideas. While this resource may be tough to utilize in a classroom, allowing students to build or view models helps students recognize various concepts that may not be implicit otherwise. It should be used to help reinforce learning of various concepts, rather than supplement material altogether (retrieved from https://sketchfab.com/).
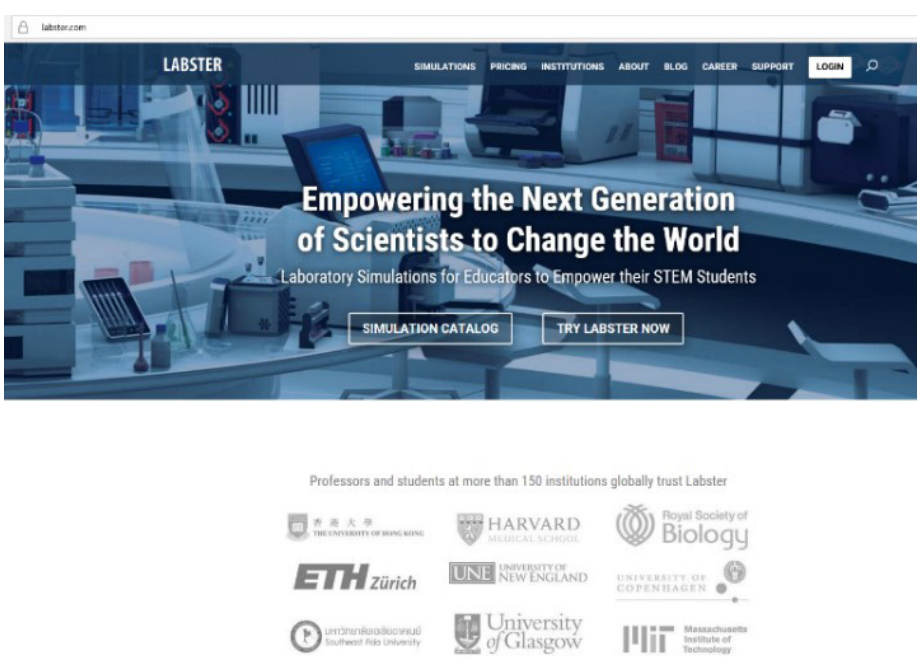

Figure 17. Labster is a website that allows teachers to utilize simulations in a variety of STEM content areas. Labster can be used as a free trial before subscribing to their resource and can easily be utilized in a classroom. This resource in particular is great for classes in an Ag Biotechnology or Food Science course (retrieved from https:// www.labster.com/).

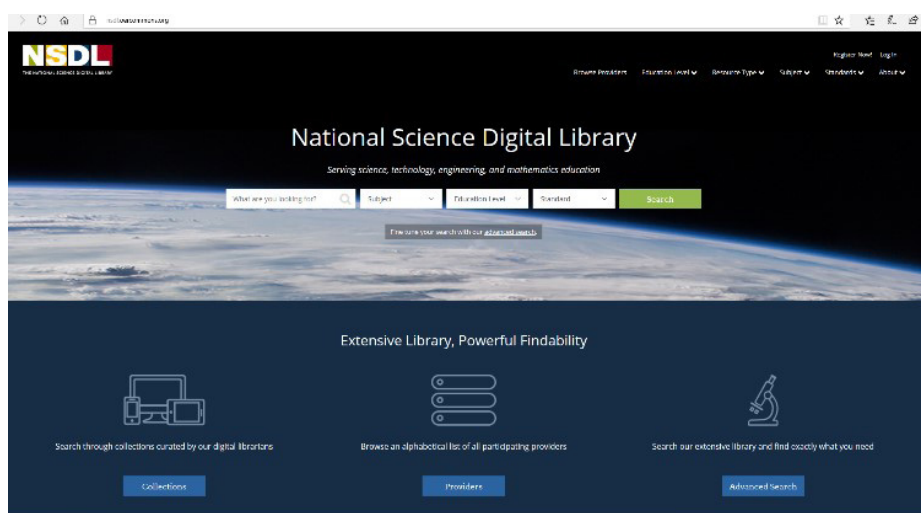

Figure 18. The National Science Digital Library offers a variety of simulations, virtual labs, and demonstrations that can be utilized within a lesson. Once entering the website, you can search for what you are looking for based off subject, education level, and content topic. Resources can range from ruminant digestion, to soil sciences, to food science, to welding (retrieved from https://nsdl.oercommons. org/).

\section{References}

American Farm Bureau Foundation for Agriculture. (2018). Free resources and lesson plans. Retrieved from http:// www.agfoundation.org/free-resources/.

America's Heartland. (2018). Education-teachers. Retrieved from http://www.americasheartland.org/education/teachers/index.html.

Career and Technical Education Online. (2018). Lesson plans. Retrieved from https://www.cteonline.org/.

Curriculum for Agricultural Science Education. (2018). Home. Retrieved from http://www.case4learning.org/.

Department of Education, Prince Edward Island. (2008). Evaluation and selection of learning resources: A guide. Retrieved from http://www.gov.pe.ca/photos/original/ ed_ESLR_08.pdf.

Florida Farm Bureau. (2018). Education and outreach. Retrieved from http://www.floridafarmbureau.org/ education-outreach/.

Georgia Agricultural Education. (2018). Curriculum and SAE. Retrieved from http://www.gaaged.org/aged/.

Heuristic. (2018). Ag education discussion lab. [Online forum]. Retrieved from https://www.facebook.com/groups/ $\underline{400575410137621 / \text { ?ref=bookmarks. }}$.

Illinois Agricultural Education. (2018) Educator resources. Retrieved from http://www.agriculturaleducation.org/ Educator-Resources. 
Labster. (2018). Home. Retrieved from https://www.labster. $\mathrm{com} /$.

MyCAERT. (2018). Home. Retrieved from http://mycaert. $\mathrm{com} /$.

National Agriculture in the Classroom. (2018). Teacher center. Retrieved from https://agclassroom.org/teacher/ index.cfm.

National Association of Agricultural Educators. (2018).

Communities of practice. Retrieved from https://communities.naae.org/welcome.

National FFA Organization. (2018). Educator resources.

Retrieved from https://www.ffa.org/resources/educators.

National Science Digital Library. (2018). Home. Retrieved from https://nsdl.oercommons.org/.

Sketchfab. (2018). Home. Retrieved from https://sketchfab. $\mathrm{com} /$.

The Agricultural Experience Tracker. (2018). Teacher Help. Retrieved from http://learn.theaet.com/default. aspx? ID $=7450$.

University of Florida. (2018). Institute of Food and Agricultural Sciences. Retrieved from http://ifas.ufl.edu/.

WISE: Web-Based Inquiry Science Environment. (2018).

Home. Retrieved from https://wise.berkeley.edu/. 